\title{
PENGARUH SUPERVISI KEPALA SEKOLAH DAN MOTIVASI BERPRESTASI GURU TERHADAP KINERJA MENGAJAR GURU
}

\author{
WINCE INDRIANI ZAI
}

G-mail : wincezai01@gmail.com

\begin{abstract}
ABSTRAK
Telah dilakukan pengamatan dan survei tentang pengaruh supervisi kepala sekolah dan motivasi berprestasi guru terhadap kinerja guru.Dalam hal ini pengaruh supervisi kepala sekolah sangat berkaitan erat dengan prestasi guru karena motivasi guru merupakan hal yang utama untuk mengembangkan peserta didik.Pengaruh supervisi kepala sekolah harus memberi pengaruh yang positif secara bersama-sama terhadap kinerja mengajar guru.Dari hasil penelitian menunjukan a).Gambaran supervisi kepala sekolah,b).Gambaran motivasi berprestasi guru,c).Pengaruh supervisi kepala sekolah terhadap motivasi berprestasi guru,d).Pengaruh motivasi berprestasi guru terhadap kinerja mengajar guru,e).Pengaruh supervisi kepala sekolah terhadap kinerja mengajar guru,f).Pengaruh supervisi kepala sekolah dan motivasi berprestasi guru terhadap kinerja mengajar guru.
\end{abstract}

Kata kunci:Supervisi kepala sekolah dan kinerja mengajar guru

\section{LATAR BELAKANG}

Pendidikan merupakan kunci untuk meningkatkan sumber daya manusia Indonesia yang unggul.Oleh karena itu,profesi guru menjadi sangat menentukan sebagai ujung tombak pembangunan sumber daya manusia Indonesia yang berkualitas dan unggul.Untuk memwujudkan sumber daya manusia yang berkualitas dan unggul pemerintah sebagai regulator mempunyai kewajiban untuk mencetak para guru yang berkualitas dan unggul pula.

Dari sekian banyak faktor yang dapat mempengaruhi kinerja mengajar guru di sekolah adalah supervisi dan motivasi.Dengan adanya supervisi kepala sekolah maka sangat penting untuk memperbaiki dan meningkatkan kinerja mengajar guru.

Sebagai hambatan internal,yaitu kinerja guru yang pada dirinya tidak adanya motivasi berprestasi sangat menentukan terhadap peningkatan kinerja mengajar guru.Pada hakekatnya gurulah yang bertanggung jawab atas peserta didik dibawah bimbingannya dengan meningkat prsetasi belajar peserta didik.

Jadi pendekatan tersebut sebagaimana dikemukakan oleh Sabandi (Sabandi, 2013) dan rismawan supervisi kepala sekolah dan motivasi guru tersebut dilakukan dengan meningkatkan motivasi guru terhadap kinerja mengajarnya. 


\section{PEMBAHASAN}

\section{Apakah Supervisi kepala sekolah berpengaruh pada terhadap motivasi berprestasi guru?}

Berdasarkan hasil analisis model struktural yang menguji pengaruh supervisi kepala sekolah terhadap motivasi berprestasi guru dan diketahui bahwa setiap peningkatan supervisi kepala sekolah akan meningkatkan motivasi berprestasi guru dan apabila terjadi setiap penurunan supervisi kepala sekolah maka akan menurunkan motivasi berprestasi guru. Untuk menguji supervisi kepala sekolah dan motivasi berprestasi guru terhadap kinerja guru maka digunakanlah SEM (structural equation model) dengan menggunakan program SIMPLIS (Simple lisrel).Program tersebut digunakan untuk pengolahan data yang sedang diteliti.Rismawan(rismawan, 2015)

Dalam menciptakan kondisi yang kondusif hendaknya para kepala sekolah dalam melaksanakan kegiatan supervisi harus memperhatikan asas-asas supervisi,yaitu (a) Supervisi pendidikan adalah bagian terpadu dari program pendidikan,(b) tujuan supervisi pendidikan adalah meningkatkan mutu pendidikan di sekolah dalam rangka mencapai tujuan pendidikan nasional,(c) pelaksanaan supervisi pendidikan hendaknya dilaksanakan secara musyawarah,saling menghormati dan bersedia menerima pendapat orang lain,(d) supervisi pendidikan hendaknya memperhatikan kesejahteraan personal pendidikan yang meliputi kebutuhan perseorangan dan sosialnya.

\section{Apakah motivasi berprestasi guru berpengaruh terhadap kinerja mengajar guru?}

Sama halnya dengan supervisi kepala sekolah terhadap kinerja guru,motivasi berprestasi guru juga berpengaruh terhadap kinerjanya.Untuk itu apabila motivasi guru mengalami peningkatan maka kinerja mengajarnya juga akan meningkat namun sebaliknya jika motivasi guru menurun maka kinerjanya juga akan mengalami penurunan.

Motivasi guru sendiri berawal dari keinginan dalam dirinya berbuat baik dan menyelesaikan tugas dengan baik,keinginan untuk unggul,dan adanya usaha dan kerja keras.

\section{KESIMPULAN}

Dalam melaksanakan kegiatan supervisi pendidikan oleh kepala sekolah hendaknya melaksanakan dengan pendekatan yang baik serta menggunakan komunikasi yang baik.Kepala sekolah juga harus melaksanakan supervisi ini secara rutin sehingga permasalahan-permasalahan yang dihadapi oleh guru dapat teratasi dengan baik dan cepat. 


\section{REFERENSI}

Rismawan, E. (2015). Pengaruh Supervisi Kepala Sekolah Dan Motivasi Berprestasi Guru Terhadap Kinerja Mengajar Guru. Jurnal Administrasi Pendidikan, XXII(1), 114-132.

Sabandi, A. (2013). Supervisi Pendidikan Untuk Pengembangan Profesionalitas Guru Berkelanjutan. Pedagogi, Jurnal Ilmiah Ilmu Pendidikan, XIII(2), 1-9. Retrieved from http://ejournal.unp.ac.id/index.php/pedagogi/article/view/4275 